\title{
Does ASEAN-Korea FTA Reduce Poverty in Laos? The Roles of FDI and Trade Facilitation
}

\author{
1, 2Jeong-Soo $\mathrm{OH}^{*},{ }^{1}$ Phouphet KYOPHILAVONG \\ ${ }^{1}$ National University of Laos, Lao PDR \\ ${ }^{2}$ Kunming University of Science and Technology, Lao PDR \\ *sabaidee.oj@gmail.com
}

\begin{abstract}
The objective of this paper is to attempt to quantify the impact of the ASEAN-Korea Free Trade Agreement (AKFTA) on the roles of Foreign Direct Investment (FDI) and the improvement of trade facilitation for the national economy and poverty. The study uses a standard Global Trade Analysis Project (GTAP) model for this analysis. The simulation results show that with consideration to the flow of FDI and the improvement in trade facilitation. Laos has gained significantly from AKFTA. The real GDP, welfare, and household income have increased as well as improvement in Laos' trade terms and balance. In addition, the income of unskilled labor that affects the poverty level has also increased significantly. Therefore, AKFTA has increased growth and also improved income distribution in Laos.
\end{abstract}

Keywords: ASEAN-Korea FTA (AKFTA), Poverty, Income Distribution, CGE model

\section{Introduction}

The Government of Laos has designated trade facilitation as one of the most important keys to economic growth and the reduction of poverty (GoL, 2011). Laos joined the Association of Southeast Asia Nations (ASEAN) in 1997 and the ASEAN Free Trade Area (AFTA) in 1998. The ASEAN-Korea Free Trade Agreement (AKFTA) negotiations were launched in 2004, the agreement was officially signed in 2006, and the agreement came into force for Laos in 2008. The reduction in tariffs required by these free trade agreements is expected to promote exports and foreign direct investment (FDI), enhance productivity, and improve the climate for doing business. At the same time, tariff reductions are also expected to lower the price of imports and therefore increase demand for imported goods, which will in turn affect the Lao economy and its income distribution. Although Laos has achieved economic growth of around $7 \%$ during the past two decades and the incidence of poverty has dropped significantly, poverty and inequality remain significant problems (National Statistics Bureau, 2008). Because it is a small, fast growing economy with a high level of poverty, understanding how trade facilitation impacts a less developed country like Laos is particularly important. Laos is a land locked country but has rich natural resources and labor. However, the business climate is poor, and there is undiversified FDI. Trade facilitation is an important factor that can promote FDI and trade facilitation to reduce the cost of trade. There are two markets through which tariff reductions, FDI and trade facilitation can affect poverty and income inequality: the commodity market and the factor market. However, the effects of trade liberalization vary by country and so it is unclear exactly how poverty and income inequality will be affected as a result of these changes. To the best of our knowledge, there is no study on the impact of AKFTA on the Lao economy and its income distribution that uses the Computable General Equilibrium (CGE) approach. This study's main objective is to attempt to quantify the impact of AKFTA on the national economy and its poverty by using the standard GTAP model by studying the roles of FDI and trade facilitation, which differs from other studies.

Lao economy, trade, and poverty: Despite a slowdown during the Asian financial crisis of the 1990s, economic growth rates have been high since the introduction of the New Economic Mechanism (NEM) in 1986 (see Table 1). ${ }^{1}$ Despite strong economic growth, low inflation and a stable exchange rate, Laos must still contend with at least four serious macroeconomic challenges. First, the government has consistently experienced budget and trade balance deficits. Second, there is a huge gap between savings and investment. Third, there is a high external debt burden. Fourth, the Lao economy depends highly on resource sectors (Kyophilavong and Toyoda, 2008). Since the introduction of a market mechanism in 1986, Laos has faced a large trade deficit. Laos imports most products from other countries, including light and heavy manufacturing goods, processed food, textiles, and clothing; imports from Thailand accounted for 60\% of all imported goods in 2008 (Table 2; 3). Laos' main export commodities in 2004

${ }^{1}$ Kyophilavong and Toyoda (2008) argue that the resource sector (mining and hydropower) has driven this growth. 
were textiles and clothing, light manufacturing, and mining production. However, the export structure of the country has since changed. Heavy manufacturing held the highest share of exports in 2008, higher than textiles, clothing, and mining (Table 4; 5). The main export destinations were Thailand, the European Union, East Asia, and Vietnam. This distribution shows that Lao trade was highly dependent upon Asian countries, especially its neighbors. Because the tariff rates for Laos and its trading partners were already low, Laos might not have gained much from the affects of AFTA through tariff cuts.

Table 1: Macroeconomic development in Laos, 1990-2011

\begin{tabular}{lllll}
\hline Macroeconomic indicator & $\mathbf{2 0 0 6 - 2 0 1 1}$ & $\mathbf{2 0 0 1 - 2 0 0 5}$ & $\mathbf{1 9 9 6 - 2 0 0 0}$ & $\mathbf{1 9 9 0 - 1 9 9 5}$ \\
\hline GDP (current million US\$) & 5,739 & 2,130 & 1,617 & 1,276 \\
GDP growth (\%) & 8.02 & 6.24 & 6.17 & 6.28 \\
GDP per capita (constant 2000 US\$) & 509 & 371 & 302 & 243 \\
GDP per capita growth (\%) & 6.43 & 4.58 & 4.00 & 3.44 \\
$\begin{array}{l}\text { Inflation, CPI (\%) } \\
\text { Trade balance (million US\$) }\end{array}$ & 5.42 & 10.31 & 57.00 & 15.27 \\
Trade balance/GDP (\%) & -320 & -228 & -276 & -174 \\
Budget deficit(including grants, & -5.41 & -10.43 & -17.03 & -13.02 \\
US\$) & -136 & -87 & -79 & -107 \\
Budget deficit/GDP (\%) & & & & \\
Exchange rate (kip per US\$) & -2.53 & -4.13 & -4.87 & -7.95 \\
\hline Soung & 8,885 & 10,164 & 4,094 & 727 \\
\hline
\end{tabular}

Sources: The World Bank's online database 'World Development Indicators.', and the Asian Development Bank's online database 'Key indicators for Asia and the Pacific 2012'

Table 2: Imports by commodity (\%)

\begin{tabular}{|l|c|c|}
\hline & 2004 & 2008 \\
\hline Grains and crops & 1.74 & 1.48 \\
Livestock and meat products & 0.25 & 0.26 \\
Mining and extraction & 2.70 & 1.28 \\
Processed food & 15.03 & 10.12 \\
Textiles and clothing & 10.19 & 6.44 \\
Light manufactring & 18.44 & 26.77 \\
Heavy manufacturing & 46.58 & 49.13 \\
Utilities and construction & 0.53 & 2.46 \\
Transport and communication & 0.82 & 1.08 \\
Other services & 3.72 & 0.97 \\
\hline Total & 100.00 & 100.00 \\
\hline
\end{tabular}

Sources: GTAP data base 7 and 8.

Table 3: Imports by country of origin (\%)

\begin{tabular}{|l|c|c|}
\hline & 2004 & 2008 \\
\hline Australia, New Zealand & 1.87 & 1.20 \\
Eambodia & 0.06 & 0.00 \\
European Union 25 & 11.91 & 17.64 \\
Indonesia & 13.54 & 6.50 \\
Latin America & 0.20 & 0.24 \\
Malaysia & 0.26 & 0.10 \\
Middle East and North Africa & 0.29 & 0.62 \\
North America & 0.95 & 0.10 \\
Philippines & 2.66 & 1.49 \\
Rest of Southeast Asia & 0.03 & 0.03 \\
Singapore & 0.01 & 0.01 \\
South Asia & 5.10 & 0.44 \\
Sub-saharan Africa & 0.44 & 0.27 \\
Thailand & 1.43 & 0.22 \\
Vietnam & 53.67 & 66.06 \\
Rest of the world & 5.70 & 4.16 \\
\hline Total & 1.85 & 0.91 \\
\hline
\end{tabular}

Sources: GTAP data base 7 and 8. 
Table 4: Exports by commodity (\%)

\begin{tabular}{|l|c|c|}
\hline & 2004 & 2008 \\
\hline Grains and crops & 5.62 & 4.36 \\
Livestock and meat products & 0.90 & 0.46 \\
Mining and extraction & 9.00 & 10.07 \\
Processed food & 1.56 & 1.05 \\
Textiles and clothing & 27.26 & 12.74 \\
Light manufacturing & 21.20 & 9.73 \\
Heavy manufacturing & 4.91 & 42.87 \\
Utilities and construction & 1.11 & 2.72 \\
Transport and communication & 12.76 & 9.90 \\
Other services & 15.67 & 6.11 \\
\hline Total & 100.00 & 100.00 \\
\hline
\end{tabular}

Sources: GTAP data base 7 and 8.

Table 5: Exports by country (\%)

\begin{tabular}{|l|c|c|}
\hline & 2004 & 2008 \\
\hline Australia, New Zealand & 0.64 & 0.78 \\
Cambodia & 0.05 & 0.01 \\
East Asia & 7.11 & 15.75 \\
European Union 25 & 46.29 & 24.65 \\
Indonesia & 0.14 & 0.38 \\
Latin America & 0.97 & 1.01 \\
Malaysia & 0.16 & 2.49 \\
Middle East and North Africa & 2.34 & 0.50 \\
North America & 11.16 & 7.67 \\
Philippines & 0.05 & 0.07 \\
Rest of Southeast Asia & 0.00 & 0.01 \\
Singapore & 0.53 & 0.50 \\
South Asia & 0.39 & 0.78 \\
Sub-sahara Africa & 0.55 & 0.93 \\
Thailand & 15.79 & 27.87 \\
Vietnam & 10.63 & 13.31 \\
Rest of the world & 3.20 & 4.06 \\
\hline Total & 100.00 & 100.00 \\
\hline
\end{tabular}

Sources: GTAP data base 7 and 8.

The Lao Expenditure and Consumption Surveys (LECS) illustrate the changes in poverty and inequality Laos has experienced over the last twenty years. The poverty rate has steadily dropped since the first LECS was administered in the early 1990's, from a high of 46\% in LECS 1 (1992/93), to 39\% in LECS 2 (1997/98), 33.5\% in LECS 3, and the most recent figure of 28\% in LECS 4 (2007/08) (Table 6). LECS also indicates that the level of inequality has also changed, though less consistently. Inequality increased between LECS 1 and LECS 2, but declined by LECS 3 (WB and DOS, 2009). 
Table 6: Poverty and inequality in Laos

\begin{tabular}{lllll}
\hline Poverty in Laos & LECS 1 & LECS 2 & LECS 3 & LECS 4 \\
& $\mathbf{1 9 9 2 / 9 3}$ & $\mathbf{1 9 9 7 / 9 8}$ & $\mathbf{2 0 0 2 / 0 3}$ & $\mathbf{2 0 0 7 / 0 8}$ \\
\hline $\begin{array}{l}\text { Lao PDR } \\
\text { Urban }\end{array}$ & 46 & 39.1 & 33.5 & 28 \\
$\begin{array}{l}\text { Rural } \\
\quad \text { - with road }\end{array}$ & 27 & 22 & 20 & 17 \\
$\quad$ - without road & 43 & 32 & 31 & 30 \\
\hline
\end{tabular}

Sources: WB and DOS (2009).

\section{Literature Review}

The conceptual framework behind the link between trade policy and poverty was first developed by Winters (2000). The impact of trade on poverty is a complex and multidimensional phenomenon. The evidence on trade facilitation and poverty falls under four headings: macroeconomic aspects (growth and fluctuations), households and markets, wages and employment, and government revenue and spending (Winters et al., 2004). The results of experienced trade facilitation are mixed. There are both positive and negative impacts in the studies on the accession of trade facilitation. Some scholars find a positive impact on trade facilitation, for example, from the regional agreement (the East Asian FTA) that yielded higher economic welfare gains and a greater economic impact (Kitwiwattanachai et al., 2009). An FTA within ASEAN tends to reduce the returns to labor of the developed non member countries and narrow the income gap between ASEAN members (Ariyasajjakorn et al., 2009). Fukase and Martin (1999) argue that the AFTA effects for Vietnam were small. The AFTA was a more efficient allocation of resources among Vietnam's industries. It benefits were moving the agriculture sector to labor-intensive manufacturing that increased the welfare (income) and was economically beneficial. Adam and Park (1995) indicate that ASEAN was better off with AFTA because the trade volume within ASEAN grew, and the positive effects increase. Park, Park and Estrada (2012) find that AKFTA has created welfare and output gains in most of the member countries because of positive net trade creation and net welfare effects. Kawai and Wignaraja (2008) find that AKFTA has generated positive income effects for Korea and other ASEAN countries. Based on the deviations in equivalent variations, the highest gains accrued to Vietnam, Korea, and Thailand while the lowest gains accrued to Less Developed Countries (LDCs).

On the other hand, some scholars find a negative impact from AFTA. Panagariya (1993) declares that AFTA was a "wrong turn." He gives several reasons for this wrong turn. First, ASEAN had small internal markets, thereby limiting the potential for internal market expansion. Second, the region had low levels of intra-regional trade. Finally, the larger countries had higher levels of protection, and he suggests that they were offering little in the way of product facilitation in the first few years. An advanced country gains more than a low income country. Adam and Park (1995) argue that the FTA is an additional burden on the government's budget and trade accounts those results in inflation. Ando and Urata (2006) find that individual ASEAN countries, in particular Thailand and Singapore, have benefitted from AKFTA. They show that the impacts of the FTA on individual countries are mixed and that the impact highly depends on the characteristics of FTA and the country's economic structure. But there is very little research on trade facilitation and poverty topic that uses quantitative methods on Laos. Kyophilavong (2004) find that the AFTA increases real consumption and investment that increases the GDP, but the increase is small. Kyophilavong, Takamatsu, and Ko (2010) find that the benefits from WTO accession are quite small. To the best of our knowledge, there is no study on the effects of AKFTA on Lao economy.

Foreign Direct Investment plays important roles in economic development. According to the empirical studies, trade facilitation promotes FDI in many countries. Francois and McDonald (1996) explore the linkage between trade policy and investment in a GTAP Model. They examine the linkages between trade facilitation and multiliteral investment emphasize the effects related to investment and the accumulation of capital. When policy shocks are capital friendly, investment is greater than the current savings rate. Brown and Stern (2000) find that the welfare effects of services facilitation is quite large, and the imporvement in the scale of production contributes to the welfare gain for capital importing countries. By contrast, the welfare effects for countries that experience capital outflow are generally negative. In addition, the improvement in trade facilitation also reduces the cost of trade (Stone and Strutt, 2009; 
Minor and Tsigas, 2008). The empirical studies show that trade facilitation can be improved through the improvement of rules, regulations, and the implementation of agreement on cross-broder trade.

\section{Methodology and scenarios}

To evaluate the effect of AKFTA on the Lao economy, poverty and inequality, we used the Global Trade Analysis Project (GTAP) model, a multi-region CGE model frequently used to analyze the impact of trade policies (Hertel, 1997). The GTAP model assumes perfectly competitive markets. The regional household allocates expenditures across three categories: private household, government, and savings. It derives income from the "sale" of primary factors to the producers that combine them with domestically produced and imported intermediate composites to produce final goods. A global bank intermediates between global savings and regional investments by assembling a portfolio of regional investment goods and selling the shares in this portfolio to regional households to meet their savings demands (Hertel, 1997). The production structure in the GTAP model is illustrated in Figure 1.

\section{Figure 1: Production structure (GTAP model)}

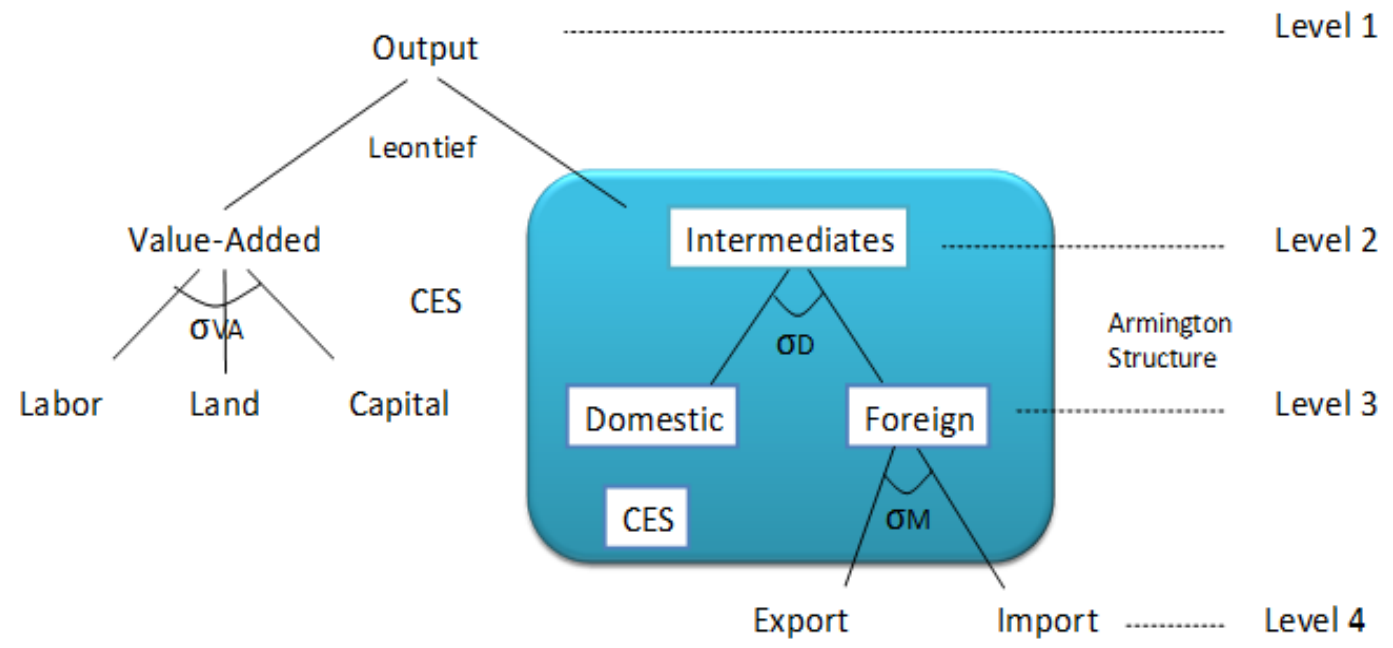

Source: Hertel (1997)

This study uses the newest version of the GTAP database. Version 8 reflects the world economy in 2012. The database is formatted as an input-output structure within each country with bilateral international trade values. To facilitate our analysis, we have aggregated all of the sectors into 57 sectors and 12 regions (Kyophilavong, 2012). In order to analyze the effects of AKFTA on the Lao Economy and its income distribution, we use the following simulations:

Simulation scenario 1: reducing tariff: This simulation shows the impact of AKFTA on the Lao economy through reduced tariff rates. We assume that the Common Effective Preferential Tariff (CEPT) Scheme for the AKFTA will reduce to $0 \%$ in $2015 .^{2}$

Simulation scenario 2: Improve trade facilitation: This simulation considers the improvement of trade facilitation through AKFTA by trade facilitation and in time costs reducing overall trade costs. This approach is followed by Hertel, Walmsley, and Itakura (2001), Minor and Tsigas (2008), and Stone and Strutt (2009). We assume a reduction in costs of $25 \%$ in the Lao economy. ${ }^{3}$

Simulation scenario 3: Increasing FDI: Through AKFTA, we assume that Laos will gain FDI from Korea and other countries. Trade facilitation could promote FDI (Brown and Stern (2000), Binh and Haughton

\footnotetext{
${ }^{2}$ We do not consider the effects from the service sector.

${ }^{3}$ We will shock ams(i,r,s) $10 \%$ for reducing cost by $25 \%$ (From Laos to ASEAN countries and from ASEAN countries to Laos)
} 
(2002), and Okamoto (1994)). By improving institutions and thus the climate for doing business, AKFTA might result in increased FDI for Laos. We assume that the FDI inflow will increase by about $25 \% .{ }^{4}$

Simulation scenario 4: Effect of AKFTA: We combine the three simulation scenarios together to show the impact of AKFTA on the Lao economy and its poverty.

\section{Results}

The result of the tariff eliminations between Laos (with ASEAN) and Korea on selected macroeconomic variables is shown in table 7. These eliminations have positive impacts on GDP and welfare, but the impacts are relatively small. The real GDP increases about $0.17 \%$, and welfare increases about USD 12 million from the baseline of 2008. The terms of trade improve with AKFTA. However, the trade deficits increase. Laos faces a trade deficit of about USD 37 million per year with AKFTA. There are positive and negative impacts from AKFTA on output in Laos. The positive sectors are light and heavy manufacturing (table 8). The top positive sector is motor vehicles and parts, which is Korea's major industrial product. On the other hand, some sectors lose with AKFTA (table 9). The agricultural sectors in particular seem to suffer negative impacts from AKFTA. The impact of AKFTA on returns to factors of production is shown in table 10. Following the literature, we assume that the changes in the income returns of unskilled labor relates to a change in poverty because most of the poor in Laos are unskilled labor. AKFTA increases the returns to land (3.42\%), unskilled labor (2.35\%), skilled labor $(2.47 \%)$, and capital $(2.28 \%)$. Clearly, AKFTA is good for poverty in the case of Laos. However, a deeper analysis on the impact of AKFTA on poverty needs to be considered.

Table 7: Macroeconomic results on AKFTA

\begin{tabular}{|l|c|c|c|c|}
\hline \multicolumn{1}{|c|}{$\begin{array}{c}\text { Macroeconomic variables } \\
\text { Simulation }\end{array}$} & $\begin{array}{c}\text { Tariff cut } \\
(1)\end{array}$ & $\begin{array}{c}\text { Trade facilitation } \\
(2)\end{array}$ & $\begin{array}{c}\text { FDI } \\
(3)\end{array}$ & $\begin{array}{c}\text { AKFTA Effects } \\
(1)+(2)+(3)\end{array}$ \\
\hline Real GDP (\%) & 0.05 & 3.28 & 10.58 & 13.9 \\
Welfare(equivalent variation) (\$US million) & 13.73 & 240.68 & 286.1 & 540.87 \\
Household income (\%) & 0.9 & 14.39 & 8.88 & 24.17 \\
Terms of Trade (\%) & 0.67 & 6.00 & -3.79 & 2.88 \\
Trade balance (\$US million) & -6.95 & -66.78 & 127.15 & 53.41 \\
\hline
\end{tabular}

Source: Authors' simulations

Table 8: Top 10 sectors for positive impact of output from AKFTA

\begin{tabular}{|c|c|c|}
\hline No & Sector & AKFTA Effect $(\%)$ \\
\hline 1 & Metals & 77.17 \\
2 & Machinery and equipment & 54.71 \\
3 & Electricity & 42.31 \\
4 & products & 40.3 \\
5 & Ferrous metals & 30.97 \\
6 & Water & 29.3 \\
7 & Motor vehicles and parts & 29.06 \\
8 & Water transport & 21 \\
9 & Trade & 20.23 \\
10 & Dwellings & 18.33 \\
\hline
\end{tabular}

Source: Authors' simulations

\footnotetext{
${ }^{4}$ We will shock qo("Capital", REG) is the variable for capital endowment and it is set as exogenous under the standard GTAP model.
} 
Table 9: Top 10 sectors for negative impact of output from AKFTA

\begin{tabular}{|c|c|c|}
\hline No & Sector & AKFTA Effect(\%) \\
\hline 1 & Sugar & -53.39 \\
2 & Leather products & -35.5 \\
3 & Crops & -31.37 \\
4 & Textiles & -23.26 \\
5 & Vegetable oils and fats & -18.41 \\
\hline 6 & Dairy products & -16.39 \\
7 & Cereal, grains & -8.22 \\
8 & Wearing apparel & -8.18 \\
9 & Oil seeds & -7.62 \\
10 & Gas & -1.44 \\
\hline
\end{tabular}

Source: Authors' simulations

Table 10: Change in returns to factor of production

\begin{tabular}{|l|c|c|c|c|}
\hline \multicolumn{1}{|c|}{$\begin{array}{c}\text { Factor of production } \\
\text { Simulation }\end{array}$} & $\begin{array}{c}\text { Tariff cut } \\
(1)\end{array}$ & $\begin{array}{c}\text { Trade facilitation } \\
(2)\end{array}$ & $\begin{array}{c}\text { FDI } \\
(3)\end{array}$ & $\begin{array}{c}\text { AKFTA Effects } \\
(1)+(2)+(3)\end{array}$ \\
\hline Returns to land & 1.36 & 18.7 & 12.24 & 32.31 \\
Returns to un-skilled labor & 0.96 & 13.73 & 7.63 & 21.36 \\
Returns to skilled labor & 1.12 & 13.72 & 6.58 & 21.43 \\
Returns to capital & 1.03 & 12.77 & -17.84 & -3.09 \\
\hline
\end{tabular}

Source: Authors' simulations.

\section{Conclusion}

The main objective of this study is to investigate the impact of the ASEAN-Korea FTA (AKFTA) on the national economy and poverty in Laos. We use the Global Trade Analysis Project (GTAP) model. There are four simulation scenarios in our study. Our simulation results show that the increase in FDI and the improvement of trade facilitation from AKFTA allows Laos to gain significantly from AKFTA. The return for unskilled labor (poverty) also increases significantly. In conclusion, AKFTA has a positive impact on the macroeconomic variables: real GDP, welfare, household income, and trade terms and balance. By tariff cut alone, AKFTA could not bring more benefits to Laos without the improvement in the business climate through attracting more FDI and improving trade facilitation. Therefore, policymakers should consider improving the business climate by attracting more FDI. In addition, because Laos is a landlocked country with poor infrastructure and trade facilitation, one of the most important factors is to improve these two factors to promote exports to enhance economic development.

\section{References}

Adam, F. G. \& Park, I. (1995). Measuring the Impact of AFTA: An Application of a Linked CGE System. Jouranl of Policy Modeling, 17(4), 325-365

Ando, M. \& Urata, S. (2006). The Impact of East Asia FTA: A CGE Simulation Study, Paper presented at the JSPS (Kyoto University)-NRCT (Thammasat University) Core University Program Conference, Emerging developments in East Asia FTA/EPAs, Doshisha University, 27-28 October.

Ariyasajjakorn, D., Gander, J. P., Ratanakomut, S. \& Reynolds, S. E. (2009). ASEAN FTA, distribution of income, and globalization. Journal of Asian Economics, 20, 327-335

Asian Development Bank. (2012). Key Indicators for Asia and the Pacific 2012, http://www.adb.org/publications/key-indicators-asia-and-pacific-2012

Binh, N. N. \& Haughton, J. (2002). Trade liberalization and foreign direct investment in Vietnam. ASEAN Economic Bulletin, 19(3). 
Brown, D. K. \& Stern, R. M. (2000). Measurement and Modeling of the Economic Effects of Trade and Investment Barriers in Servies, Research Seminar in International Economics, School of Public Policy, The University of Michigan, Ann Arbor, Michigan 48109-1220, Discussion Paper No.453.

Francois, J. \& McDonald, B. (1996). Liberalization and Capital Accumulation in the GTAP Model, GTAP Technical Papers, Paper 8, http://docs.lib.purdue.edu/gtaptp/8

Fukase, E. \& Martin, W. (1999). Evaluating the Implications of Vietnam's Accession to the ASEAN Free Trade Area (AFTA), Development Research Group, World Bank

GoL. (2011). The National Growth and Poverty Eradication Strategy (NGPES), Committee of Planning and Investment, Vientiane, Laos

Hertel, T. W. (1997). Global Trade Analysis: Modeling and Applications, Cambridge University Press

Hertel, T., Walmsley, T. \& Itakura, K. (2001). Dynamic Effects of the New Age Free Trade Agreement between Japan and Singapore, GTAP Working Papers, Paper 15, http://docs.lib.purdue.edu/gtapwp/15

Kawai, M. \& Wignaraja, G. (2008). Regionalism as an Engine of Multilarelism: A Case for a Single East Asia FTA, ADB Working Paper Series on Regional Economic Integration No.14, Asian Development Bank, Manila

Kitwiwattanachai, A., Nelson, D. \& Reed, G. (2009). Quantitative impacts of alternative East Asia Free Trade Areas: A Computatble General Equilibrium (CGE) assesment. Journal of policy modeling, 32, 286-301

Kyophilavong, P. (2004). Analyzing the effect of AFTA on Lao economy: Macroeconomic model approach, ESRI Asia Workshop on Econimic Modeling on Deepening Interrelationships among Asian Countries, November 30, Bangkok, Thailand

Kyophilavong, P. \& Toyoda, T. (2008). Impact of Foreign Capital Inflows on the Lao Economy., in Toyoda eds., Empirical Research on Trad and Finance in East Asia. Hiroshima Shudo University

Kyophylavong, P., Takamatsu, P. \& Ko, J. (2010). The impact of Laos' Accession to the World Trade Organization, Thirteen Annual Conference on Global Economic Analysis, 15 APR 2010.

Kyophilavong, P. (2012). The Impact of Global Financial Crisis on Lao Economy: GTAP Model Approach. Journal of US-China Public Administration, 9(3), 280-289.

Minor, P. \& Tsigas, M. (2008). Impacts of Better Trade Facilitation in Developing Countries, Conference Paper, GTAP 11th Annual Conference, Helsinki, Finland.

National Statistics Bureau. (2008). Poverty in Lao PDR 2008.

Okamoto, Y. (1994). Impact of trade and FDI liberalization policies on the Malaysian economy. The Developing Economies, 32(4), 460-478.

Panagariya, A. (1993). Should East AsianGo Regional? No, No, and Maybe, Trade Policy Research Papers, Regional integration Initiative Study, October, World Bank.

Park, D., Park, I. \& Estrada, G. B. (2012). The Prospects of ASEAN-Korea Free Trade Area (AKFTA): A Qualitative and Quantitative Analysis. ASEAN Economic Bulletin, 29(1), 29-45.

Stone, S. \& Strutt, A. (2009). Transportation Infrastructure and Trade Facilitation in the Greater Mekong Subregion, ADBI Working Paper Series, No. 130, Asian Development Bank, Tokyo.

Winters, L. A. (2000). Trade and Poverty: Is There a Connection? in Trade, Income Disparity and Poverty, Ben David, D., Nordstrom, H., Winters, L. A. eds., Special Study 5, Geneva: WTO.

Winter, L. A., Mculloch, N. \& Mckay, A. (2004). Trade Liberalization and Poverty: The Evidence So Far. Journal of Economic Literature, XLII, 72-115.

World Bank., DOS. (2009). Lao PDR: Recent Economic Developments, World Bank Vientiane Office, Laos

World Bank. (2012). World Development Indicators 2012, http://data.worldbank.org/datacatalog/world-development-indicators/wdi-2012. 